\title{
Multidrug Resistant Pattern and Plasmid Detection of Escherichia coli from Various Sources within the University of Port Harcourt
}

\author{
Obakpororo Ejiro Agbagwa, Oyi Nato Okorafor, Seleipiri Jemina Horsfall \\ Department of Microbiology University of Port Harcourt, Choba, Rivers State, Nigeria \\ Email: obakpororo.agabgwa@uniport.edu.ng, ejiroagbagwa@yahoo.com
}

How to cite this paper: Agbagwa, O.E., Okorafor, O.N. and Horsfall, S.J. (2022) Multidrug Resistant Pattern and Plasmid Detection of Escherichia coli from Various Sources within the University of Port Harcourt. Open Journal of Medical Microbiology, 12, 11-23.

https://doi.org/10.4236/ojmm.2022.121002

Received: December 8, 2021

Accepted: February 27, 2022

Published: March 2, 2022

Copyright $\odot 2022$ by author(s) and Scientific Research Publishing Inc. This work is licensed under the Creative Commons Attribution International License (CC BY 4.0).

http://creativecommons.org/licenses/by/4.0/

\section{(c) (i) Open Access}

\begin{abstract}
Multi-drug resistance (MDR) in Enterobacteriaceae poses critical public health threat in Nigeria and the global world. This resistant mechanism might be plasmid mediated or chromosomal. Escherichia coli are Gram negative pathogen with a global distribution rate. The study was carried out to determine MDR and plasmid profiling of E. coli isolates from urine, feaces and poultry litter. The samples were cultured on eosine methylene blue agar and incubated for 24 hours at $37^{\circ} \mathrm{C}$. Results obtained showed a percentage prevalence of $30 \%$ for the urine samples which were the most prevalent, while the prevalence of $E$. coli from the feacal and poultry litter was $8 \%$ and $28 \%$ respectively. Identified $E$. coli were screened for antibiotic susceptibility by Kirby Bauer diffusion method. The results on susceptibility of $E$. coli to tested antibiotics before plasmid curing showed $100 \%$ resistance to cefuroxime and augumentin, while $75 \%$ resistance was observed in gentamicine, ciprofloxacin and ofloxacine. Cefixime and cefdazidime resistance were $62.5 \%$ on $E$. coli and the least resistance was observed in nitrofurantion (25\%). The poultry litter and urine isolates recorded lower resistance level to antibiotics, compared to the feacal isolates. After plasmid curing the percentage of resistance reduced. The only antibiotics that responded positively was nitrofurantion, with high sensitivity of $87 \%$ for feacal isolate, $100 \%$ for urine isolates, and $78 \%$ for poultry litter isolates after plasmid curing. Twenty (20) of the thirty seven (37) isolates were still resistant to more than two antibiotics after the plasmid curing. Of the twenty isolates, 18 (90\%) were found to harbor single plasmid, while 2 (10\%) did not possess plasmid. This study concludes that nitrofurantion was the most effective antibiotics on Escherichia coli and plasmids were responsible partly for resistance.
\end{abstract}

\section{Keywords}

Escherichia coli, Multidrug, Plasmid, Resistance 


\section{Introduction}

Multidrug resistance (MDR) in Enterobacteriaceae poses critical public health threat in Nigeria and the global world as a whole. This resistant mechanism might be plasmid mediated which is due to the presence of transferable plasmids that encodes multidrug resistance [1]. Some of the resistant genes found in Enterobacteriaceae are carried on the plasmid which also aids their transfer [2] [3]. Multidrug resistant pathogenic bacteria from different sources causing infection occur due to several factors such as plasmids transfer or mediated which is self-replicating [4]. Escherichia coli are Gram negative pathogen rod shaped, non-sporulating, non-fastidious, motile, and facultative anaerobic bacterium with a global distribution rate. It can be isolated from environmental, clinical and animal sources. Certain strains of $E$. coli cause most clinical and environmental mediated diseases. Although the development of MDR is a natural phenomenon, the inappropriate use of drugs, inadequate sanitary conditions, inappropriate food handling, poor infection prevention and control practices has contributed to the emergence of MDR and encourages the further spread of MDR. The continuous deployment of antimicrobial drugs in treating infections has led to the emergence of resistance among various strains of microorganisms and the consequences of these results in ineffective treatment and spreading of infection [5]. The aspect of treating bacterial infections in modern medicine is less effective as a result of the global spread of antimicrobial resistance. Multidrug resistance is said to occur as resistance to all the tested antibiotics in at least two of the three classes: lactams, aminoglycosides, and quinolones [6]. Studies [1] detected higher levels of MDR from aquatic isolates and loss of plasmid due to treatment with SDS is correlated with loss of resistance to antibiotics, suggesting that the observed multi-drug resistance was plasmid mediated. E. coli have also been shown to be a significant reservoir of genes coding for antimicrobial drug resistance and therefore are a useful indicator for resistance in bacterial communities. Resistant mechanism could be as a result of horizontal transfer of genes, mutation, and antibiotic overuse among other contributing factors. Multi-drug resistance ability exhibited by bacterial organism renders an antibiotic less effective in disease treatment and management. These resistant genes can be found in the environment at higher levels [7].

Multidrug resistant does not only emerge in pathogenic and disease causing organisms, but also communal strains like Escherichia coli (E. coli), which is a member of the normal flora that is found in the gastrointestinal tract of human and warm blood animals [8]. E. coli is generally used as an indicator organism, and greatly dispersed in the natural environment (water, soil, sometimes plants used as food) through human or animal excretion. It is transmitted through Feacal-oral route [9]. The existence of $E$. coli in nature is vast, it ranges from exhibiting commensalism, to those that cause disease on human or animal host [10]. When the commensal E. coli are exposed to antibiotics, they are forced to develop different strategies to survive and grow in toxic environment. E. coli can 
develop resistance mechanism mainly by both efflux pumps interruption and the resistance genes located on plasmid. The main vector in the procurement and propagation of multi-resistance is plasmid, it can be either phenotypic or genotypic [11]. The study aims to determine multi-drug resistant pattern and plasmid detection of resistant $E$. coli from various sources.

\section{Methodology}

\subsection{Study Area/Design}

The study was centered around Choba Rivers State, Clinical samples (fecal and urine) were obtained from the medical laboratory at University of Port-Harcourt Teaching Hospital (UPTH); while the environmental samples (poultry litter) were obtained randomly within Choba. The research was designed to determine multi-drug resistant pattern and plasmid profiling of Escherichia coli from various sources within Choba, Rivers State. To identify multi-drug resistant E. coli isolates, and determine if the resistant genes is plasmid mediated or chromosomal.

\subsection{Sample Collection and Processing}

Clinical samples (fecal and urine) were obtained from the medical laboratory at University of Port-Harcourt Teaching Hospital (UPTH); while the environmental samples (poultry litter) were obtained randomly within Choba. Samples were collected in sterile containers. A total of 50 samples were collected for the laboratory analysis. Environmental samples were processed immediately on Eosin Methylene blue Agar (EMB) using the spread plate method. The clinical samples were cultured directly on EMB by streaking. The fecal samples were first emulsified with $0.85 \%$ normal saline, and cultured directly on EMB. Cultures were then incubated at $37^{\circ} \mathrm{C}$ for $24 \mathrm{hrs}$. Biochemical identification test such as catalase, oxidase, urease, indole, Methyl red, Voges proskaeur, citrate utilization, sugar fermentation test, motility test and Tripple sugar iron (TSIA) were done accordingly to specifically identify and confirm that the isolates were $E$. coli.

\subsection{Antibiotic Susceptibility Testing}

Antibiotics susceptibility testing was done using Mueller Hinton agar by Kirby -Bauer disc diffusion method following NCCLS recommendations using ceftazidime $30 \mu \mathrm{g}$, cefuroxime $30 \mu \mathrm{g}$, gentamicin $10 \mu \mathrm{g}$, Cefixime $5 \mu \mathrm{g}$, Ofloxacin $5 \mu \mathrm{g}$, Augmentin $30 \mu \mathrm{g}$, Nitrofurantion $30 \mu \mathrm{g}$, Ciprofloxacin $5 \mu \mathrm{g}$. A sterile inoculating loop was used to pick a colony of the isolate, and it was inoculated into a tube of sterile water of $5 \mathrm{ml}$ and mixed properly. The turbidity of the suspension was matched with the turbidity standard ( $0.5 \mathrm{McF}$ arland turbidity Standard). A sterile cotton swab was dipped into the test suspension and used to evenly inoculate the entire surface of the Mueller Hinton Agar plates (MHA). The appropriate antibiotics disc were placed on the surface and pressed gently using sterile forceps. The plates were then incubated for 24 hours at $35^{\circ} \mathrm{C}$. The antibiotics sus- 
ceptibility pattern was determined after 24 hours, and the zones of inhibition were measured in millimeter [12].

\subsection{Plasmid Curing and Profiling}

Plasmid curing was done using Acridine orange. Plasmid elimination was done through culturing in $5 \mathrm{ml}$ double strength Mueller Hinton broth by which 0.1 $\mathrm{mg} / \mathrm{ml}$ acridine orange was added [13]. The isolates that were found resistant from the antimicrobial susceptibility testing was inoculated into the test tubes and incubated at $37^{\circ} \mathrm{C}$ for $24 \mathrm{hrs}$. Plasmid DNA extraction was done using Zyppy plasmid Miniprep Kit. The extracted DNA was then separated by agarose gel electrophoresis and a Polaroid camera was used to take a photograph after exposure on UV trans-illuminator [14].

\subsection{Plasmid DNA Extraction and Plasmid Profiling}

The plasmids from the bacterial isolates were extracted using the Zyppy Plasmid Miniprep kit suppled by Inqaba Biotec South Africa. To $600 \mathrm{ul}$ of overnight Luria Bertani (LB), broth culture of the bacterial isolates in a $1.5 \mathrm{ml}$ microcentrifuge tube, $100 \mathrm{ul}$ of $\times 7$ lysis buffers was added and mixed by inverting tube for 2 min, $350 \mathrm{ul}$ of neutralization buffer was added and mixed till neutralization was complete. The mixture was spun at $12 \mathrm{rpm}$ for $2 \mathrm{mins}$, the supernatant was transferred to into a Zymo-spin IIN column which was placed in a collection tube and spun at $12,000 \mathrm{rpm}$ for $1 \mathrm{~min}$, the flow through was discarded and the spin column placed back in the same collection tube. Two hundred (200) microlitres of endo wash buffer was added and spun at 12,000 rpm for $1 \mathrm{~min}, 400 \mathrm{ul}$ of wash buffer was also added to the spin column and spun at 12,000 rpm for 1 min. The spin column was transferred to a new $1 \mathrm{ml}$ microcentrifuge tube, 300 $\mathrm{ul}$ of elution buffer was added to the spin column and spun at 12,000 rpm for 1 $\mathrm{min}$. Agarose gel was prepared by dissolving $1 \mathrm{~g}$ of the agarose powder in $100 \mathrm{~m}$ 1 of Tris boric EDTA (TBE) and microwaved for $5 \mathrm{~min}$. The agarose was allowed to cool, ethidium bromide was added and poured into a casting tray in which a comb was fixed. The agarose was allowed to set and the comb was carefully removed. The agarose slab was transferred to an electrophoretic tank and ran at $100 \mathrm{~V}$ for $50 \mathrm{~min}$. The slab was resolved on a UV transilluminator for the detection of the plasmid bands (https://files.zymoresearch.com/), (Short protocol, Zyppy Plasmid Miniprep Kit).

\section{Results}

The biochemical test carried out to identity the isolates were shown to be indole positive, catalase positive, Citrate negative, Glucose positive, Gas present, Methyl Red positive, Voges Proskauer negative, and motile. Gram stain showed that all the isolates were Gram negative rod. A total of 37 isolates from the 50 samples were identified and confirmed to be Escherichia coli using standard microbiological methods. 
The prevalence $E$. coli was higher in the urine samples (30\%), compared with the poultry litter (28\%), and the feacal samples (16\%) as shown in Table 1.

Figures 1-3 shows the results of antibiotics susceptibility study of isolates before and after plasmid curing, the resistant level of CRX, GEN, CXM, OFL, Table 1. Percentage prevalence of E. coli from various sources.

\begin{tabular}{cccc}
\hline Sample source & No. of samples & No. of E. coli & Prevalence (\%) \\
\hline Poultry litter & 20 & 14 & 28 \\
Feacal & 15 & 8 & 16 \\
Urine & 15 & 15 & 30 \\
\hline
\end{tabular}

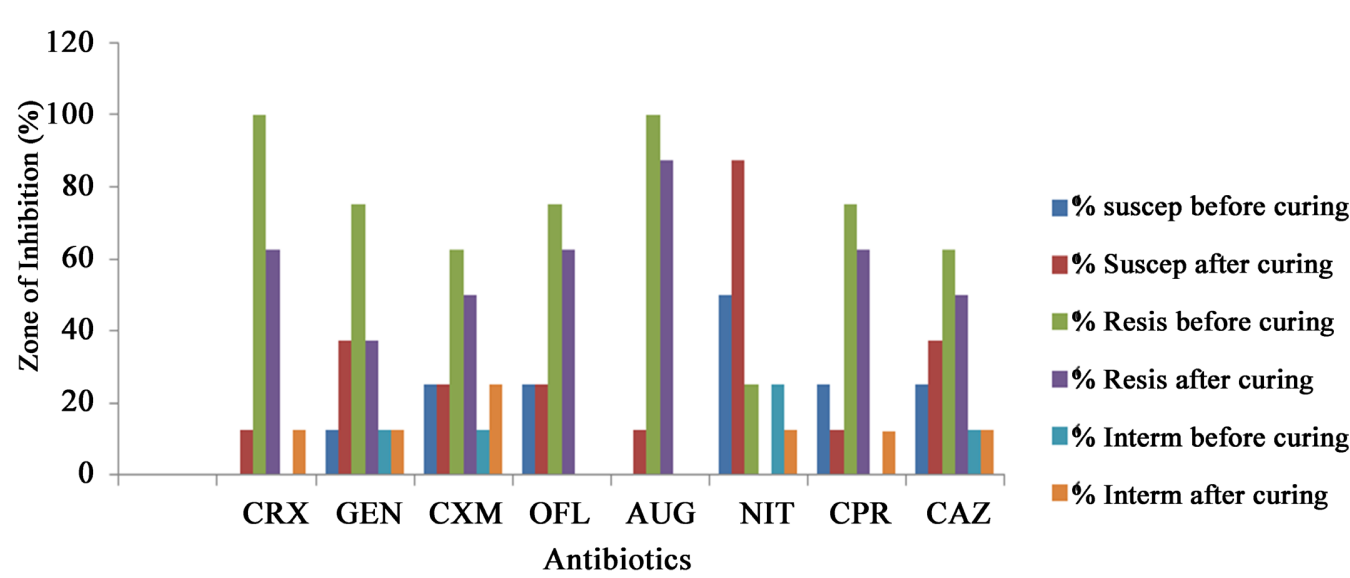

Figure 1. Antibiotics susceptibility pattern of $E$. coli from feacal samples before and after curing.

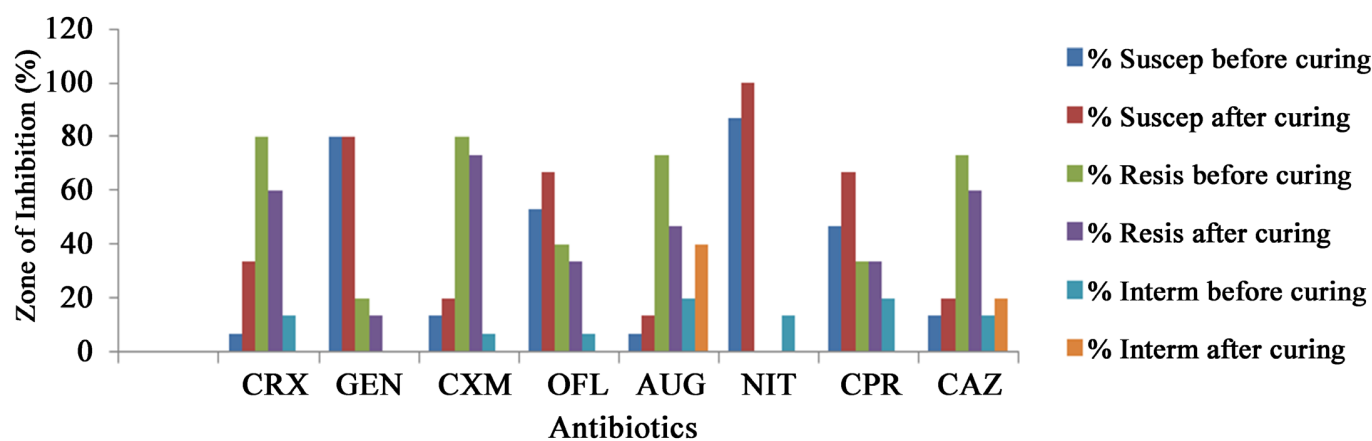

Figure 2. Antibiotics susceptibility pattern of $E$. coli from urine samples before and after curing.

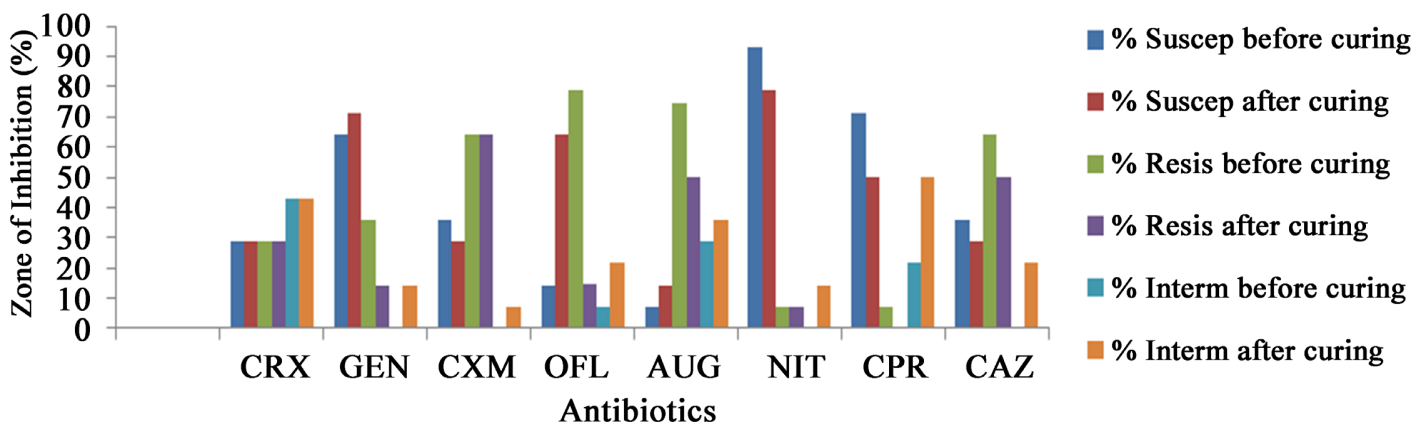

Figure 3. Antibiotics susceptibility pattern of $E$. coli from poultry litter before and after curing. 
AUG, CPR and CAZ was high ranging from 62.5\% - 100\%. Feacal isolates ranged from $20 \%-80 \%$, while poultry litter had $28.6 \%-78.6 \%$. NIT recorded lower resistance of about $25 \%$ for Feacal isolate, $0 \%$ for Urine isolate, and $7.2 \%$ for poultry isolates. After plasmid curing, the isolates responded positively to the antibiotics used and there was a drastic reduction in the resistance level. CRX, GEN, CXM, OFL, AUG, CPR and CAZ which had values of 37.5\% - 87.5\% for feacal isolates, $13.3 \%-73.3 \%$ for the urine isolates, and $14.3 \%-64.3 \%$ for the poultry isolates. NIT recorded $0 \%$ for feacal isolates, $0 \%$ for the urine isolates, and $7.2 \%$ for the poultry isolates after curing.

Twenty (20) out of thirty seven (37) E. coli isolates that were resistant to more than two antibiotics after plasmid curing, were subjected to plasmid profiling. Isolates code PL2 (poultry litter 2) and US4 (urine sample 4), recorded no plasmid. Other isolates showed plasmids bands at $15 \mathrm{~kb}$, with 1 plasmid number each. This is represented in Table 2, and Figure 4. Percentage resistance, susceptibility and intermediate were determined for all the isolates as presented in Figures 5-7. Plasmid curing had no significant effect on the resistance level on the feacal isolates. The urine and poultry litter.

Table 2. Plasmid profile of Escherichia coli.

\begin{tabular}{|c|c|c|}
\hline Isolate code & Plasmid size (kb) & Number of plasmid \\
\hline Pl 1 & $15 \mathrm{~kb}$ & 1 \\
\hline Pl 8 & $15 \mathrm{~kb}$ & 1 \\
\hline Pl 12 & $15 \mathrm{~kb}$ & 1 \\
\hline Pl 14 & $15 \mathrm{~kb}$ & 1 \\
\hline Pl 18 & $15 \mathrm{~kb}$ & 1 \\
\hline Us 1 & $15 \mathrm{~kb}$ & 1 \\
\hline Us 3 & $15 \mathrm{~kb}$ & 1 \\
\hline Us 4 & No band & - \\
\hline Us 5 & $15 \mathrm{~kb}$ & 1 \\
\hline Us 6 & $15 \mathrm{~kb}$ & 1 \\
\hline Us 8 & $15 \mathrm{~kb}$ & 1 \\
\hline Us 12 & $15 \mathrm{~kb}$ & 1 \\
\hline Us 15 & $15 \mathrm{~kb}$ & 1 \\
\hline Fs 1 & $15 \mathrm{~kb}$ & 1 \\
\hline Fs 4 & $15 \mathrm{~kb}$ & 1 \\
\hline Fs 13 & $15 \mathrm{~kb}$ & 1 \\
\hline Fs 14 & $15 \mathrm{~kb}$ & 1 \\
\hline Fs 15 & $15 \mathrm{~kb}$ & 1 \\
\hline Fs 8 & $15 \mathrm{~kb}$ & 1 \\
\hline
\end{tabular}




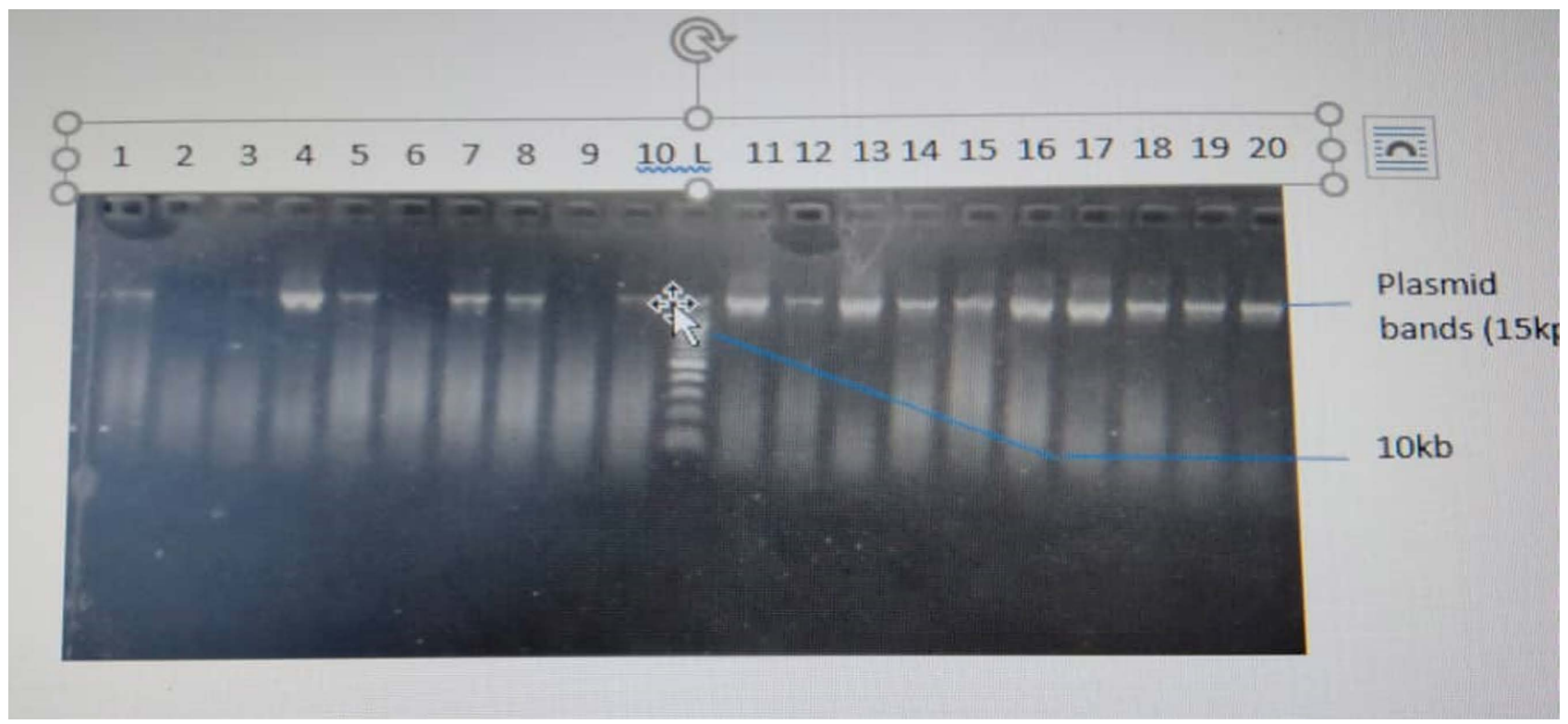

Figure 4. Agarose gel electrophoresis showing plasmid band, lanes 1, 2, 3, 4, 5, 6, 7, 8, 9, 10-20 showing the plasmid band at $15 \mathrm{~kb}$ while lane $\mathrm{L}$ represent the $10 \mathrm{~kb}$ molecular ladder.

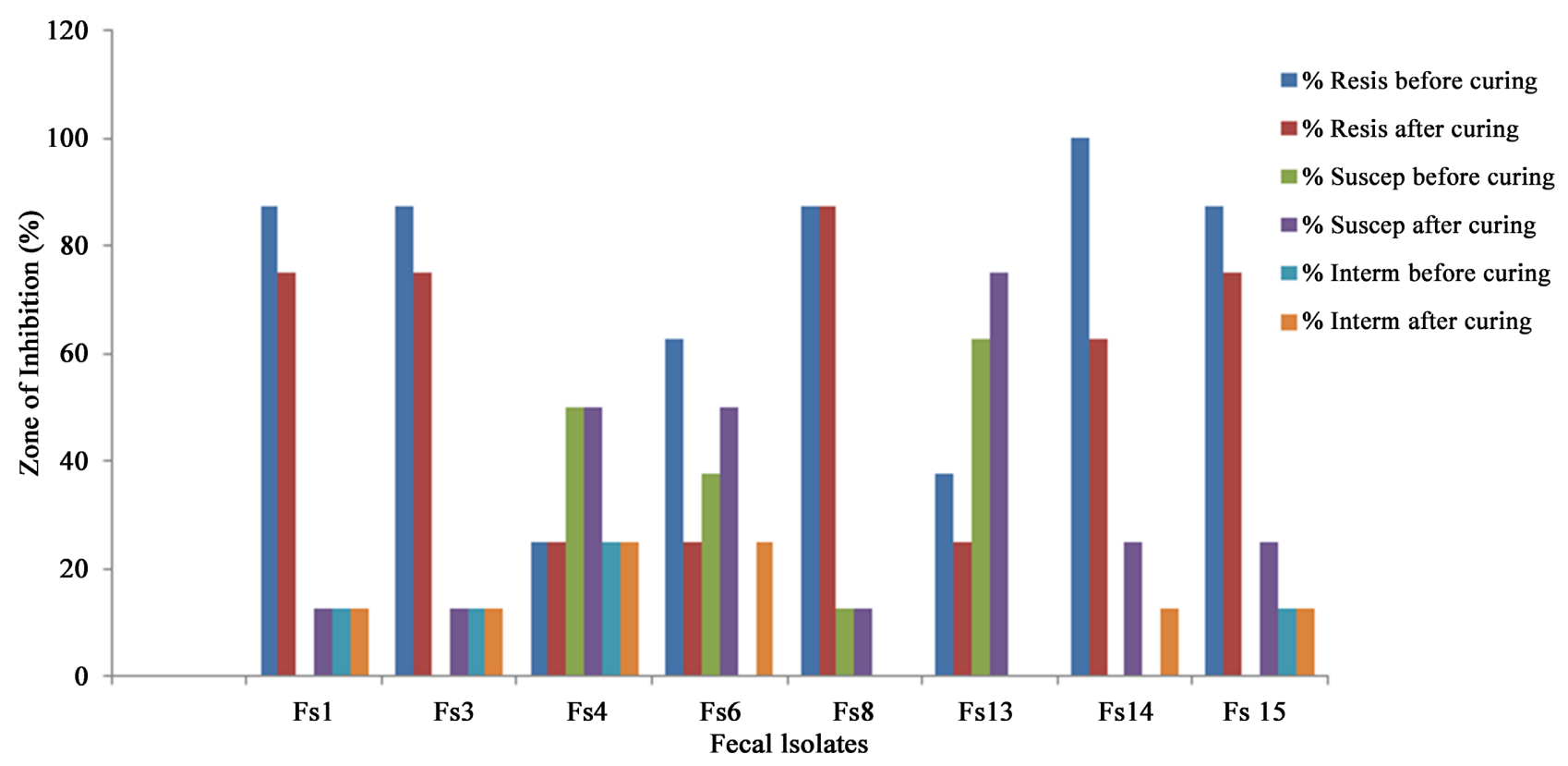

Figure 5. Percentage resistance, sensitivity, and intermediate of feacal E. coli before and after curing.

\section{Discussion}

Emergence of bacterial resistance to antimicrobial agents has become a significant and prevalent public health threat especially when there are few or no available alternative effective antimicrobial agents for the treatment of infectious diseases caused by bacteria. Though most strains of E. coli are harmless and commonly found in humans and animals, some strains can cause severe illness in humans especially nosocomial and community acquired infections. In this present study, the multi drugs pattern of E. coli from various sources (urine, 


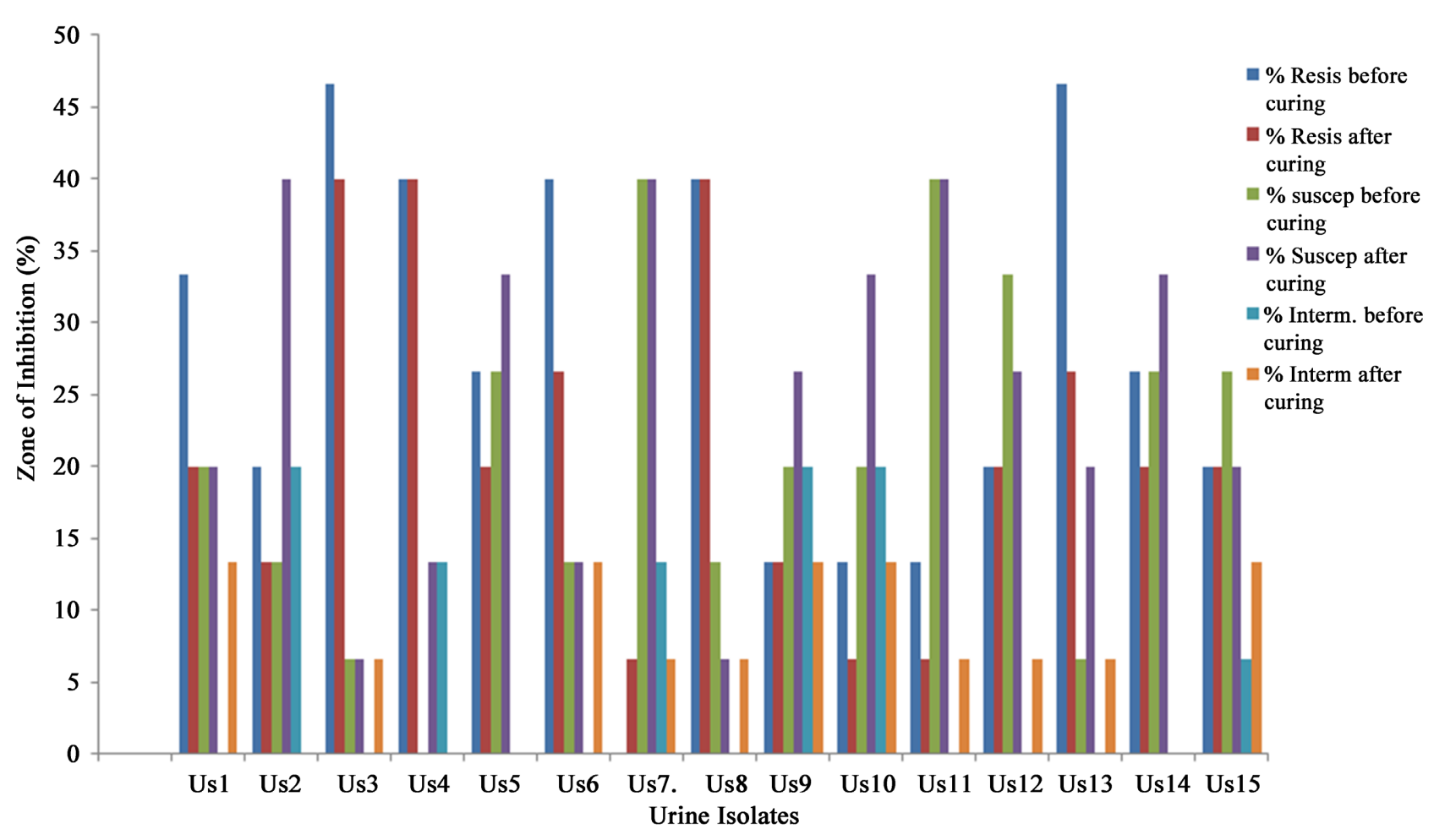

Figure 6. Percentage resistance, sensitivity, and intermediate of $E$. coli from urine before and after curing.

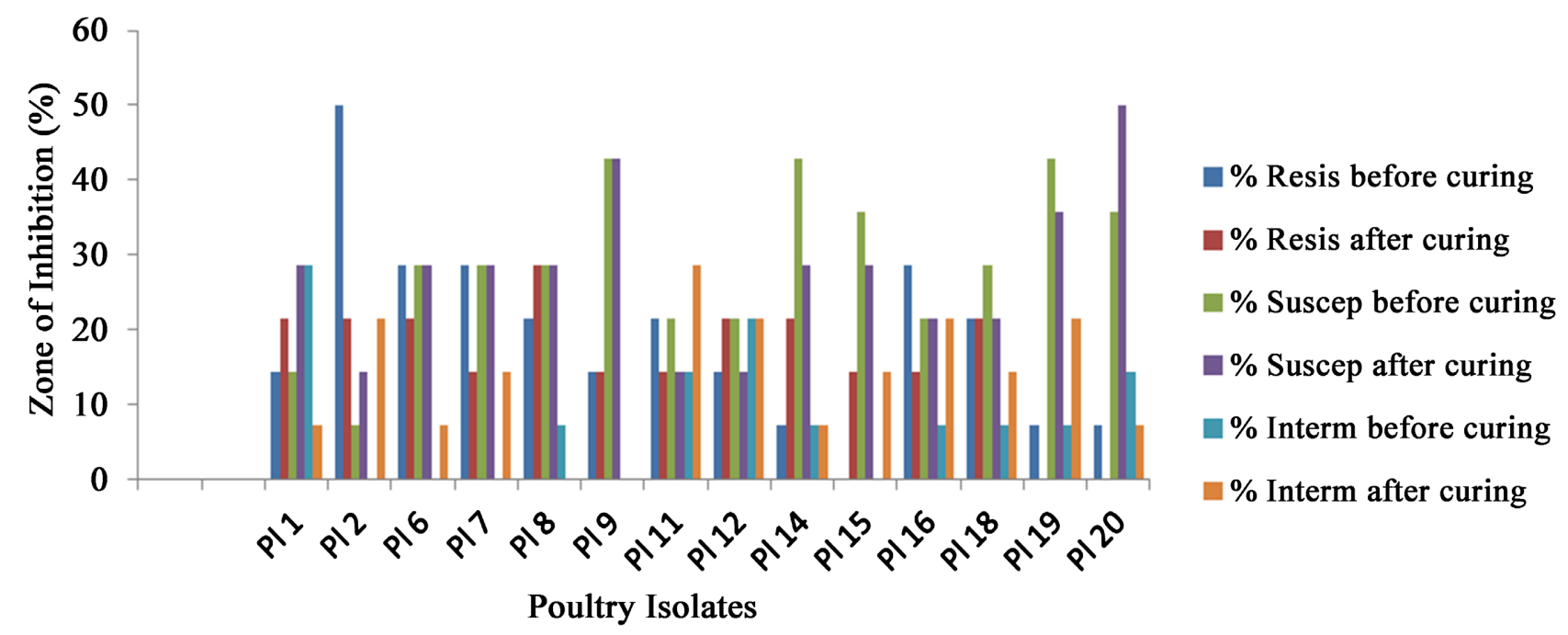

Figure 7. Percentage resistance, sensitivity, and intermediate of E. coli from poultry litter before and after curing.

feaces, and poultry) were investigated. Previous studies show that antimicrobial resistance varies widely depending on the country or source from which the microorganisms have been isolated [15]. In this study the percentage prevalence of E. coli varied, significantly from one source to the other. The highest occurrence of $E$. coli (30\%) was from the urine samples and the least was the feacal (8\%). The present study is in conformity with the findings of Thapa et al. [16]) where out of 2662 urine samples, E. coli (64.34\%) was highest in occurrence. It has been observed that antibiotic susceptibility of bacterial isolates is not constant, 
but dynamic and varies, with time and environment. Hassan [17] [18] in their study reported high percentage resistance of $E$. coli to ciprofloxacin, ceftazidime and ceftriaxone, while nitrofurantoin and ofloxacin recorded the least resistance levels of $6.0 \%$ and $19.0 \%$ respectively among the $E$. coli isolates which is confirmatory to the present study. In the present study, an overall prevalence of MDR among the isolates was maximum of $100 \%$ for most antibiotics and minimum of $7.2 \%$ for nitrofurantion only before plasmid curing. The poultry litter and urine isolates recorded lower resistance level to antibiotics, compared to the feacal isolates. After plasmid curing the percentage of resistance reduced which shows that plasmids maybe responsible for part of the resistance in some of the identified isolates. The findings may be as a result of bacteria organisms developing mechanism with which they resist these antibiotics, or the presence of plasmids, or the source from which it's isolated. Several antibacterial drugs have been developed to curb the morbidity and mortality effect of these bacteria. Previous studies have shown MDR of E. coli 44.4\%, 69.0\%, 56.0\%, 13.7\%, 37.1\% for Egypt, Portugal, France, South Africa and Jordan [19] [20] [21] [22]. This might be due to inappropriate or excessive use of antibiotics for therapeutic and prophylactic treatment [23] [24]. The only antibiotics that responded positively was Nitrofurantion, with high sensitivity of $87 \%$ for feacal isolate, $100 \%$ for urine isolates, and $78 \%$ for poultry litter isolates, after plasmid curing. Even before plasmid curing, the sensitivity level was high, compared to other antibiotics used. An earlier study in the same study settings had shown high sensitivity of $E$. coli to nitrofurantoin at $100 \%$ sensitivity rates [25]. Likewise, another study reported a similar susceptibility of $78 \%$ [26]. The increasing resistance could be due to increased overuse and misuse of antibiotics or plasmid mediated. Furthermore, it has been rarely used in the treatment of E. coli related diseases and other infections and therefore present organisms present low resistance to it since they have not been frequently exposed to it [27] [28]. Escherichia coli isolates were highly resistant to cefuroxime (100\%) and augmentin (100\%) which was so alarming in this study. The resistance in a previous study in Mulago Hospital was significantly lower [26]. Resistance to gentamicin (75\%), ciprofloxacin (75\%), and Ofloxacin (75\%), was also alarming and this was similar to a related study in $\mathrm{Mu}$ lago which reported $89.9 \%$ resistance of E. coli [25]. This resistance could be due to previously increased use of these drugs or plasmid mediated as in this study. And also these drugs are relatively cheaper and readily available, this could have rendered them easily accessible to the patients, increasing their misuse and overuse, leading to resistance.

Plasmid can mediate antibiotics resistance by several mechanisms which vary among Gram negative bacteria. E. coli produces 1 of the 3 enzymes ( $\beta$-lactamase) that are responsible for antibiotics alteration and degradation, which render the antibiotics inactive. This enzyme is coded by both chromosome and plasmid, another popular mechanism is the efflux of antibiotics that is responsible for the presence of multicomponent pumps found in Gram negative bacteria [29]. To 
find the causes of antibiotics resistance, the presence of plasmid DNA was analyzed for resistant $E$. coli isolates in this study. It was observed that all resistant isolates contained plasmid with molecular weight of approximately $15 \mathrm{~kb}$. Agarose gel Electrophorosis shows the plasmid bands at lane 1 to 20 at $15 \mathrm{~kb}$, while lane $\mathrm{L}$ represents the $10 \mathrm{~kb}$ molecular ladder, with single plasmid. This agrees favorably with previous studies that reported $E$. coli isolates with high multi-drug resistance profiles were found to possess multiple plasmids with large sizes in the range of $6.557-23.130 \mathrm{~kb}$ [30]. This is also similar to what was reported that 47 of the $E$. coli isolated from animals in Lagos harboured detectable plasmids which ranged in sizes from $0.564 \mathrm{~kb}$ to $>23 \mathrm{~kb}$ [31]. Multiple plasmids in multi-drugs resistant E. coli may act as possible sources to transfer highly resistant genes to pathogenic organisms and human that could be a threat for the treatment of disease by commercially available antibiotics. Other bioactive components and peptides can be detected for the effective treatment of infections caused by MDR E. coli that are resistant to last resort antibiotics [31].

\section{Conclusion}

The study therefore concludes that Escherichia coli isolates were most susceptible to Nitrofurantion only, and resistant to ceftazidime, cefuroxime, gentamicin, cefixime, ofloxacin, augumentin, and ciproflaxacin. This study has also highlighted the emergence of multidrug resistant R-plasmids among Escherichia coli from urine, feaces, and poultry litter in Choba. This demonstrates an increasing incidence with multidrug resistant $E$. coli. All the resistant isolates were harbored single plasmids. Caution should be taken in the prescription of antibiotics. Antibiotics policy role should be established by the government.

\section{Conflicts of Interest}

The authors declare no conflicts of interest regarding the publication of this paper.

\section{References}

[1] Chigor, V.N., et al. (2010) Multidrug Resistance and Plasmid Patterns of Escherichia coli $\mathrm{O} 157$ and Other E. coli Isolated from Diarrhoeal Stools and Surface Waters from Some Selected Sources in Zaria, Nigeria. International Journal of Environmental Research and Public Health, 7, 3831-3841. https://doi.org/10.3390/ijerph7103831

[2] Kayastha, K., Dhungel, B. and Karki, S. (2020) Extended-Spectrum $\beta$ Lactamase-Producing Escherichia coli and Klebsiella Species in Pediatric Patients Visiting International Friendship Children's Hospital, Kathmandu, Nepal. Infectious Diseases, 13, 1-7. https://doi.org/10.1177/1178633720909798

[3] Woerther, P.L., Burdet, C., Chachaty, E. and Andremont, A. (2013) Trends in Human Fecal Carriage of Extended-Spectrum b-Lactamases in the Community: Toward the Globalization of CTX-M. Clinical Microbiology Reviews, 26, 744-758. https://doi.org/10.1128/CMR.00023-13

[4] Akingbade, O., Balogun, S., Ojo, D., Akinduti, P., Okerentugba, O.P., Nwanze, C.J., 
et al. (2014) Resistant Plasmid Profile Analysis of Multidrug Resistant Escherichia coli Isolated from Urinary Tract Infections in Abeokuta, Nigeria. African Health Sciences, 14, 821-828. https://doi.org/10.4314/ahs.v14i4.8

[5] Tanwar, J., Das, S., Fatima, Z. and Hameed, S. (2014) Multidrug Resistance: An Emerging Crisis. Interdisciplinary Perspectives on Infectious Diseases, 2014, Article ID: 541340. https://doi.org/10.1155/2014/541340

[6] Sentchilo, V., Mayer, A.P., Guy, L., Miyazaki, R., Green, Tringe, S. and Barry, K. (2013) Community-Wide Plasmid Gene Mobilization and Selection. ISME Journal, 7, 1173-1186. https://doi.org/10.1038/ismej.2013.13

[7] Perry, J.A., Westman, E.L. and Wright, G.D. (2014) The Antibiotic Resistome: What's New? Current Opinion in Microbiology, 21, 45-50.

https://doi.org/10.1016/j.mib.2014.09.002

[8] Katouli, M. (2010) Population Structure of Gut Escherichia coli and Its Role in Development of Extra-Intestinal Infections. Iran Journal of Microbiology, 2, 59-72. http://eprints.covenantuniversity.edu.ng/id/eprint/432

[9] Waturangi, D.E., Hudiono, F. and Aliwarga, E. (2019) Prevalence of Pathogenic Escherichia coli from Salad Vegetable and Fruits Sold in Jakarta. BMC Resistant Notes, 12, Article No. 247. https://doi.org/10.1186/s13104-019-4284-2

[10] van Elsas, J.D., Semenov, A.V., Costa, R. and Trevors, J.T. (2011) Survival of Escherichia coli in the Environment: Fundamental and Public Health Aspects. ISME Journal, 5, 173-183. https://doi.org/10.1038/ismej.2010.80

[11] Ochman, H. and Selander, R.K. (1984) Evidence for Clonal Population Structure in Escherichia coli. https://doi.org/10.1073/pnas.81.1.198

[12] Cheesbrough, M. (2006) District Laboratory Practice in Tropical Countries Part 1 \& 2. Second Edition Update, Cambridge University Press, Cambridge, 62, 97-115, 132-143.

[13] Tomoeda, M., Inuzuka, M., Kudo, N. and Kakamura, S. (1968) Effective Elimination of Drug Resistance and Sex Factors in Escherichia coli by Sodium Dodecyl Sulphate. Journal of Bacteriology, 95, 1078-1089. https://doi.org/10.1128/jb.95.3.1078-1089.1968

[14] Bennett, P.M. (2008) Plasmid Encoded Antibiotic Resistance: Acquisition and Transfer of Antibiotic Resistance Genes in Bacteria. British Journal of Pharmacology, 153, S347-S357. https://doi.org/10.1038/sj.bjp.0707607

[15] Selim, S.A., Ahmed, S.F., Abdel, M.H., Zakaria, A.M., Klena, J.D. and Pangallo, D. (2013) Prevalence and Characterization of Shiga-Toxin O157:H7 and Non-O157:H7 Enterohemorrhagic Escherichia coli Isolated from Different Sources. Biotechnology \& Biotechnological Equipment, 27, 3834-3842.

https://doi.org/10.5504/BBEQ.2013.0031

[16] Thapa Shrestha, U., Shrestha, S., Adhikari, N., Rijal, K.R., Shrestha, B., Adhikari, B., Banjara, M.R. and Ghimire, P. (2020) Plasmid Profiling and Occurrence of $\beta$-Lactamase Enzymes in Multidrug-Resistant Uropathogenic Escherichia coli in Kathmandu, Nepal. Infection and Drug Resistance, 13, 1905-1917. https://doi.org/10.2147/IDR.S250591

[17] Hassan, S.H. (1995) Sensitivity of Salmonella and Shigella to Antibiotics and Chemotherapeutic Agents in Sudan. The Journal of Tropical Medicine and Hygiene, 88, 243-248.

[18] Akinjogunla, O.J., Odeyemi, A.T. and Olasehinde, G.I. (2010) Epidemiological Studies of Urinary Tract Infection (UTI) among Post-Menopausal Women in Uyo Metropolis, South-South, Nigeria. Journal of American Science, 6, 1674-1681. 
http://eprints.covenantuniversity.edu.ng/432/

[19] Ramadan, H., Jackson, C.R., Frye, J.G., Hiott, L.M., Samir, M. and Awad, A. (2020) Antimicrobial Resistance, Genetic Diversity and Multilocus Sequence Typing of Escherichia coli from Humans, Retail Chicken and Ground Beef in Egypt. Pathogens, 9, 357. https://doi.org/10.3390/pathogens9050357

[20] Amador, P., Fernandes, R., Prudêncio, C. and Duarte, I. (2019) Prevalence of Antibiotic Resistance Genes in Multidrug-Resistant Enterobacteriaceae on Portuguese Livestock Manure. Antibiotics, 8, 23. https://doi.org/10.3390/antibiotics8010023

[21] Bourély, C., Cazeau, G., Jarrige, N., Jouy, E., Haenni, M. and Lupo, A. (2009) Co-Resistance to Amoxicillin and Tetracycline as an Indicator of Multidrug Resistance in Escherichia coli Isolates from Animals. Frontiers in Microbiology, 124, 189-196.

[22] Obaidat, M.M., Bani, A.E., Davis, M.A. and Roess, A.A. (2018) Major Diseases, Extensive Misuse, and High Antimicrobial Resistance of Escherichia coli in Large- and Small-Scale Dairy Cattle Farms in Jordan. Journal of Dairy Science, 101, 2324-2334. https://doi.org/10.3168/jds.2017-13665

[23] Hamid, M., Tefera, Y., Eguale, T. and Worku, Y. (2018) Escherichia coli O157:H7: Prevalence, Identification and Antimicrobial Resistance in Cattle Slaughter at Addis Ababa Municipal Abattior, Ethiopia. International Journal of Advance Research Biological Science, 5, 136-146.

[24] Majalija, S., Francis, O., Sarah, W., Lubowa, M., Vudriko, P. and Nakamya, F. (2010) Antibiotics Susceptibility Profiles of Faecal Escherichia coli Isolates from Dip-Litter Broilers Chickens in Northern and Central Uganda. Veterinary Research, 3, 75-80.

[25] Mwaka, A.D., Mayanja-Kizza, H., Kigonya, E. and Kaddu-Mulindwa, D. (2011) Bacteriuria among Adult Non-Pregnant Women Attending Mulago Hospital Assessment Centre in Uganda. African Health Sciences, 11, 182-189.

[26] Kabugo, D., Kizito, S., Ashok, D., Graham, K.A., Nabimba, R., Namunana, S., et al. (2016) Factors Associated with Community-Acquired Urinary Tract Infections among Adults Attending Assessment Centre, Mulago Hospital Uganda. African Health Sciences, 16, 1131-1142. https://doi.org/10.4314/ahs.v16i4.31

[27] Bryce, A., Hay, A.D., Lane, I.F., Thornton, H.V., Wootton, M. and Costelloe, C. (2016) Global Prevalence of Antibiotic Resistance in Pediatric Urinary Tract Infections Caused by Escherichia coli and Association with Routine Use of Antibiotics in Primary Care: Systematic Review and Meta-Analysis. BMJ, 352, i939. https://doi.org/10.1136/bmj.i939

[28] Nas, F.S., Ali, M., Abdallah, M.S. and Zage, A.U. (2019) Prevalence and Antibiotic Susceptibility Pattern of Escherichia coli Isolated from Urine Samples of Urinary Tract Infection Patients. ARC Journal of Urology, 4, 14-19. https://doi.org/10.20431/2456-060X.0401004

[29] Giedraitiene, A., Vitkauskiene, A. and Naginiene, R. (2011) Antibiotics Resistance Mechanisms of Clinically Important Bacteria. Medicina (Kaunas), 47, 137-146. https://doi.org/10.3390/medicina47030019

[30] Umolu, P.I., Omigie, O., Tatfeng, Y., Omorogbe, F.I., Aisabokhale, F. and Ugbodagah, O.P. (2006) Antimicrobial Susceptibility and Plasmid Profiles of Escherichia coli Isolates Obtained from Different Human Clinical Specimens in Lagos Nigeria. The Journal of American Science, 2, 70-75.

[31] Zhou, Q., Fan, H., Lu, P., Zhou, Y., Li, W. and Liu, J. (2018) Linear Thanatin Is an Effective Antimicrobial Peptide against Colistin-Resistant Escherichia coli in Vitro. Advances in Microbiology, 8, 589-599. https://doi.org/10.4236/aim.2018.87039 


\section{List of Abbreviations}

PLS: Poultry litter Samples

FSS: Feacal Samples

URS: Urine Samples

CAZ: CEFTAZIDIME

CRX: CEFUROXIME

GEN: GENTAMICIN

CXM CEFIXIME

OFL: OFLOXACIN

AUG: AUGMENTIN

NIT: NITROFURANTION

CPR: CIPROFLAXACIN

MDR: Multidrug Resistance 